\title{
Pre-service Teachers Perspectives towards English Teaching as a Career Option
}

\author{
Ida Ayu Mela Tustiawati \\ English Literature Study Program \\ Faculty of Foreign Languages, Universitas Mahasaraswati \\ Jalan Kamboja No.11A Denpasar 80223 \\ mela.tustiawati@unmas.ac.id
}

\begin{abstract}
Education is one of the parameters to the success of a country. As part of the education system, teachers play an important role. The teaching profession that is now considered to be a well-respected profession in society used to be considered as a way to show your dedication to the country. With the change of view towards the teaching profession, more people are attracted to this profession. However, the number of students who enroll themselves in the teaching training universities and the numbers of graduates who become teachers are not the same. Some of them may become teachers but some of them decide to choose a different career path. This study tries to identify the initial perspectives of the pre-service teachers on the English teaching as a career option through the application of questionnaires. The result shows that majority of the participants have positive perspectives towards English teaching as a career option. They view English teaching as a career that will give them a chance to work with the younger generation and help others. It is also viewed as a respectable job that is quite flexible in their application. Even though the current teaching profession offers good financial support, the finding shows that it is not the main reason why the participants decide to be a teacher.
\end{abstract}

Key words: Teaching Motivation, Pre-service Teacher, Teaching Profession, Career Option

\section{INTRODUCTION}

Education is a significant element in establishing a prosperous country. Providing a good education system for all people is not easy to achieve. One of the key factors in education is the teachers. The UNESCO Institute for Statistics (UIS) and The Education for All Global Monitoring Report (GMR) (2014) reported that there is a significant shortage of qualified teachers all over the world. Indonesia is one of the top ten countries on their list that needs new teacher recruitment by 2030 .

Teaching profession is now considered to be a well-respected job in Indonesia, but not in the past. It has been viewed as less promising and popular than other jobs (Afrianto, 2014; The World Bank, 2010). Teaching was not seen as a profession for a very long time; rather it was viewed as an individual's dedication to the country. In 2005, a new law for teachers and lecturers was issued and based on this new law, both teaching and lecturing occupations are considered to be professional jobs. They are entitled for an increase in the basic salary, and also additional incentives. As a result, many students enrolled themselves at the universities that provide teacher training.

In terms of a teacher's field of expertise, preservice teachers in Indonesia can only undertake one specific major during their study period, except for the primary pre-service teachers who are required to be qualified to teach in several subjects thematically. One of the majors that attract quite a lot of students is the English education major. Although English is not officially a second or additional language, it is considered to be one of the main foreign languages that has a big influence in Indonesia. Simatupang (as cited in Lander, 2008) explained that in Indonesia, English may not be commonly used in society but it is viewed as the most important foreign language to learn. Similarly, Suryanto (n.d) stated that the Indonesian government's decision to make English a 
compulsory subject from junior to university level is due to the role of the English language in the international community. Meanwhile, Rini (2014) related the importance of learning the English language to future opportunities; that by understanding English, people will earn higher salaries and have better opportunities in their life. A wider opportunity provided by understanding English may be one of the reasons why many students enroll themselves in the English education department.

The factors that motivate people to enter teaching have been investigated in studies of teacher education in a number of countries. Watt and Richardson (2007) found that most of the pre-service teachers in Australia decided to enter teaching mostly because of their interests and beliefs in their capability to become teachers, as well as altruistic influences. In addition, extrinsic factors also influence students' decisions, especially when future plans (e.g. raising a family) are involved (Konig \& Rothland, 2012).

A study done by Kilinc et al. (2012) in Turkey revealed a different result that most Turkey samples demonstrated altruistic "social utility values" as their main reason to choose teaching as a career, followed by the security of the job. This finding is quite similar to what Suryani et al. (2013) found in Indonesia in which family and significant others have a great influence on people's choice of career.

Understanding the reasons why pre-service teachers decide to undergo a four year training to become a teacher is important for it influence their commitment to be a teacher. It appears that not all of these pre-service teachers continue as practicing teachers when they graduate. Therefore, in this study, the researcher tries to identify the pre-service teachers' perspectives on the English teaching as a career option for them in the future.

\section{RESEARCH METHODOLOGY}

The method used in this study is a descriptive method. The study examined the work perceptions of 134 pre-service teachers who enrolled at the English Language Education Department, Faculty of Education, the Mahasaraswati University (UNMAS), Bali, Indonesia. The faculty runs the English language education course in two ways: day time and night time classes. The study recruited students from both the day time and night time classes. The participants from these two groups differed in their demographic background and their enrolment status which provides better examination of the issues.

In order for a research study to be successful, it needs to have suitable and useful measurements (instruments) that will be able to gather data appropriately (Ary et al., 2010). This study adopted a practical approach offered by the application of questionnaire to collect the data. A questionnaire used to examine the aim of the study had been developed using close-ended types of questions. The questionnaire consisted of fifteen statements about the participants' perspectives on the English teaching as a career option which were categorized into: job security, flexibility, social status, professional development, working with children/adolescents, altruism. The participants were asked to indicate the extent to which they agree or disagree with the statements.

\section{RESULTS AND DISCUSSION}

The findings of the study indicate that the participants have various views about English teaching in Indonesia. The table below illustrates that most of the students have positive perspectives on the English teaching as a career option.

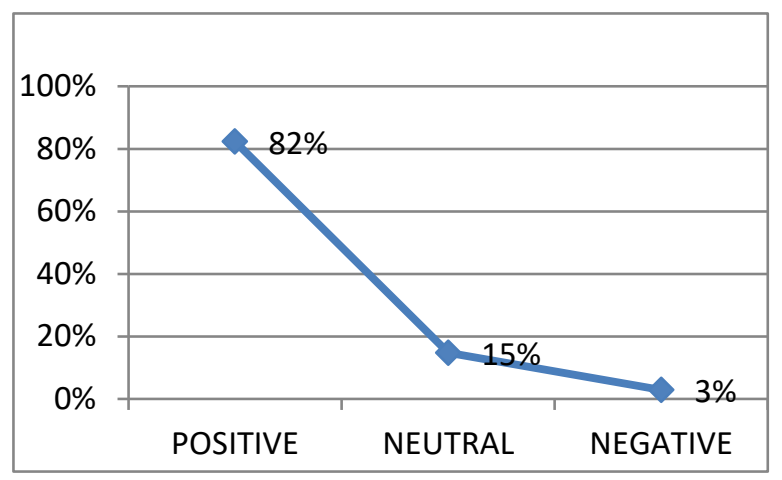

Table 1: English Teaching Perspective

This positive attitude on the teaching profession is spread evenly in the six categories of the teaching perspectives as a career option.

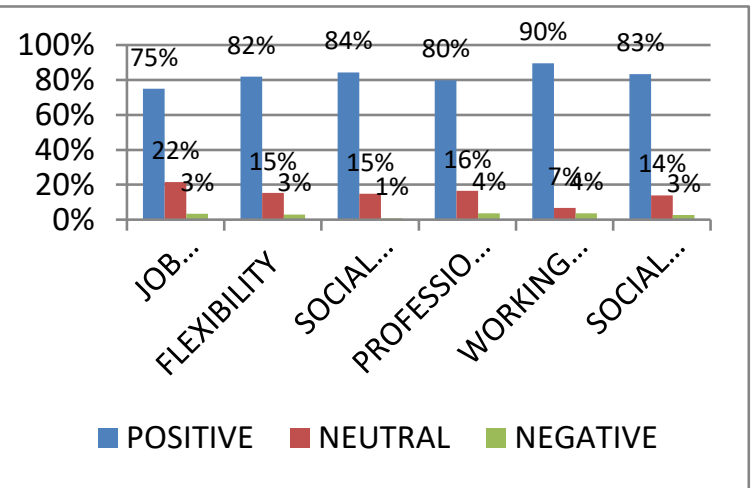

Table 2: Summary for Each Category

Based on the summary, it appears that the majority of the participants look at teaching as a socially responsible job, that is, a job that gives them a chance to work with the younger generation. This result supports the idea that younger teachers seem to look at teaching as a noble job (Afrianto 2014; Hellsten \& Prytula, 2014; Manuel \& Hughes, 2006). Many participants see the profession as altruistic, i.e., a job that helps others and a respectable job in society. It seems that if you are a teacher, the society will put trust on you and thus they respect you and your teaching profession well. 
The impact of the application of the new law for teachers and lectures can also be seen in this research that a number of participants chose teaching because of the security of the profession. However, it is not as high as the other factors.

Another view on the teaching profession based on this study is that it is a profession that offers flexibility in their application. Compared with the other profession, the teaching profession is quite flexible in terms of the working time. Furthermore, many participants relate this flexibility with the development of the tourism industry in the society. It has quite a good impact on the pre-service teachers' motivation to take the English major. By taking the English major the pre-service teachers have dual opportunities as they have wider possibility to be an English teacher or be part of the tourism industry.

\section{CONCLUSION}

The results of the study showed that the majority of participants have positive perspectives of English teaching as a career option. Most of them view English teaching as a career that offers dual opportunities and flexibility to enter both tourism and the education sectors. Although the teaching profession in Indonesia is regarded as a profession that provides financial opportunities, the finding shows the opposite that it is viewed as a chance to help others and work with the younger generation.

\section{REFERENCES}

[1] Afrianto. (2014). "Because teaching is like a plantation of dakwah": understanding complexities in choosing to be a teacher in Indonesia. Australian Journal of Education and Developmental Psychology, 14, 51-59.

[2] Ary, D., et al. (2010). Introduction to research in education. Wadsworth: Cengage Learning.

[3] Hellsten, L. M., \& Prytula, M. P. (2014). Why teaching? Motivations influencing beginning teachers' choice of profession and teaching practice. Research in Higher Education Journal, 1-19.

[4] Kilinc, et al. (2012). Factors influencing teaching choice in Turkey. Asia-Pacific Journal of Teacher Education, 40, 199226.

[5] Konig, J., \& Rothland, M. (2012). Motivations for choosing teaching as a career: effects on general pedagogical knowledge during initial teacher education. Asia-Pacific Journal of Teacher Education, 40, 289-315.

[6] Lauder, A. (2008). The status and function of English in Indonesia: a review of key factors. Makara, Social Humaniora, 12, 9-20.

[7] Manuel, J., \& Hughes, J. (2006). It has always been my dream: exploring pre-service teachers' motivations for choosing to teacher. Teacher Development: an International Journal of Teachers' Professional Development, 10, 5-24.

[8] Rini, J. E. (2014). English in Indonesia: its position among other languages in Indonesia. Beyond Words, 2, 20-40.

[9] Suryani, a., Watt, H.M.G., \& Richardson, P.W. (2013). Teaching as a career: Perspectives of Indonesian future teachers. Paper presented at the AARE Annual Conference, Adelaide 2013, 1-17.

[10] Suryanto. (n.d). Issues in teaching English in a cultural context: a case of Indonesia. Retrieved July 2015, from www.ejournal.unsri.ac.id

[11] The World Bank. (2010). Transforming Indonesia's teaching force. Jakarta: Author.
[12] UNESCO Institute for Statistics (UIS). (2014). Wanted: Trained teachers to ensure every child's right to primary education. Author.

[13] Watt, H. M. G., \& Richardson, P. W. (2007). Motivational factors influencing teaching as a career choice: development and validation of the FIT-Choice Scale. The Journal of Experimental Education, 75, 167-202. 